\title{
Diamine Oxidase Activity in Fibroblasts from Normal and Cystic Fibrosis Patients
}

\author{
WILLIAM A. GAHL ${ }^{(2 \pi)}$ AND HENRY C. PITOT \\ Departments of Oncology, Pathology, and Pediatrics, University of Wisconsin, Center for Health Sciences, Madison, \\ Wisconsin, USA
}

\section{Summary}

Diamine oxidase is the initial enzyme involved in the degradation of polyamines, whose metabolism has been reported as abnormal in cystic fibrosis (CF). Diamine oxidase activity, using putrescine as substrate, was measured in homogenates of human fibroblasts cultured in vitro from normal and cystic fibrosis patients. The pH optimum of the crude enzyme was 7.8. Diamine oxidase activity per $\mu \mathrm{g}$ protein peaked during periods of greatest proliferative rate and reached its nadir when fibroblasts grew in static (confluent) phase. No difference was found between normal and CF fibroblasts in specific activity of diamine oxidase, but CF cells exhibited a slightly lower protein content during logarithmic growth when compared with normal cells.

\section{Speculation}

Aberrations in the levels of polyamines in blood, despite normal levels of polyamine biosynthetic enzymes in fibroblasts, have been reported in $\mathrm{CF}$ patients. No differences were found between normal and CF fibroblasts in the levels of the polyamine catabolic enzyme, diamine oxidase, suggesting that an abnormality of the oxidative deamination of polyamines, as expressed in the fibroblast, is not the primary defect in CF. The altered blood levels of polyamines may be a secondary phenomenon found only in vivo, or may be due to an aberration of polyamine acetylation or conjugation. The establishment of normal values of diamine oxidase for different phases of growth of human fibroblasts may in the future allow comparison with fibroblasts in which a defect in polyamine catabolism is suspected.

In vitro studies in bacteria and higher forms of life have shown that diamine oxidase (E C 1.4.3.6.), with nonspecific activity against polyamines, diamines, and histamine, can degrade the aliphatic polyamines putrescine, spermidine, and spermine to their respective aminoaldehydes $(2,8,21)$. The in vivo significance of this enzyme in human polyamine degradation remains unknown, especially because specific polyamine oxidases, with their own $\mathrm{pH}$ optima, substrate specificities, and physical characteristics, may exist. Such individual polyamine oxidases may degrade each polyamine separately, or a single, nonspecific diamine oxidase may oxidatively deaminate all three polyamines (24). The current, most widely used assay for this general diamine oxidase employs ${ }^{14} \mathrm{C}$-putrescine as substrate (17). The authors know of no reports of this enzymatic activity in human tissue cultures, although diamine oxidase activity using putrescine as substrate has been found in human seminal fluid (14), pregnancy plasma (3), amniotic fluid (22), and tumor tissue (4).

Several investigators have reported abnormal levels or ratios of polyamines in the blood of individuals with CF $(7,19)$. Arvanitakis et al. (1) found that spermidine mimicked a factor in CF plasma by inhibiting methyl-D-glucose uptake by rat jejunal epithelium. In an attempt to discover how these findings might relate to a metabolic defect in CF, Buehler et al. (5) measured activities of the two principle enzymes involved in the synthesis of polyamines, ornithine decarboxylase and S-adenosyl methionine decarboxylase, in skin fibroblasts from normal and CF patients. No significant differences were found, and defects in the degradation of polyamines were not sought.

In this investigation, the authors examine whether human fibroblasts in culture actively degrade putrescine, how this enzymatic activity varies with rate of growth, and whether diamine oxidase activity in CF fibroblasts differs from that of normal cells.

\section{MATERIALS AND METHODS}

\section{FIBROBLAST CULTURES}

Diploid fibroblast strains, obtained from skin biopsies of six normal patients and six patients with CF were matched for cell growth rate. All cell strains studied were in less than the seventh passage. The cells were grown in F-12 medium with $15 \%$ fetal calf serum (GIBCO, Grand Island, NY) and cultured by routine procedures presented elsewhere (18). On three occasions, two different normal and two CF cell strains were plated at $8 \times 10^{3}$ cells/ml, $5 \mathrm{ml}$ per P-60 Petri dish (Falcon Plastics, Oxnard, CA). Three days later, designated day 1,15 dishes of each cell strain were washed four times with $\mathrm{pH} 7.4$ phosphate-buffered saline, scraped into a test tube, spun, and resuspended in $2 \mathrm{ml}$ of $1 / 15 \mathrm{M}$ potassium phosphate buffer, $\mathrm{pH}$ 7.8. The cells were lysed using a Polytron homogenizer for $25 \mathrm{sec}$. Homogenate containing approximately $100-200 \mu \mathrm{g}$ protein was assayed for diamine oxidase activity on the day of harvesting, and the remainder was frozen at $-20^{\circ} \mathrm{C}$. No decrease in diamine oxidase activity was noted after freezing for at least 1 wk.

On day 2, 10 P-60 dishes were harvested, and on the next 3 days, 5,4 , and 3 dishes, respectively. On day 8 , two P-60 dishes were harvested and treated as above. The cells remaining on each day were fed fresh media on days $1-5$. On each day of harvesting, two dishes of each cell strain were trypsinized and an aliquot was counted using a Model B Coulter Counter. The cells usually approached confluency between days 4-5.

\section{PROTEIN DETERMINATION}

On each day of harvesting, two dishes of each cell strain were assayed for protein using the method of Lowry et al. (16). Reagents were placed directly into each dish, releasing and lysing the cells, and aliquots were removed for the remainder of the assay procedure. In addition, aliquots of each cell strain's frozen homogenate were assayed for protein so that DNA and diamine oxidase activity could be presented per $\mu \mathrm{g}$ of measured protein.

\section{DNA DETERMINATION}

When enough cell extract was available, DNA was assayed on each day's frozen homogenate by the method of Burton (6). 
DIAMINE OXIDASE ASSAY

Diamine oxidase was assayed by a modification of the scintillation counting method of Okuyama and Kobayashi (17). In the standard reaction mixture, 6.2 nanomoles $(0.15 \mu \mathrm{Ci})$ of ${ }^{14} \mathrm{C}-\mathrm{pu}$ trescine (New England Nuclear Corp., Boston, MA) were incubated at $37^{\circ} \mathrm{C}$ for $5 \mathrm{hr}$ with enzyme (cell homogenate) and $1 / 15$ $\mathrm{M}$ potassium phosphate buffer, $\mathrm{pH} 7.8$, in a total volume of 2.0 $\mathrm{ml}$. The product was extracted with toluene, counted, and dpms converted to nanomoles of product formed, as previously described (11). One unit of diamine oxidase activity is defined as that amount of enzyme which converts 1 picomole of putrescine to product per hr under the conditions described. Assays were performed in triplicate.

\section{DETERMINATION OF DOUBLING TIMES}

The logs of cell number and protein content were plotted against day in culture, and straight lines using the least squares method were determined for the points representing days $1-4$. Doubling times were derived from the slopes of those straight lines.

\section{RESULTS}

Using 6.2 nanomoles of ${ }^{14} \mathrm{C}$-putrescine substrate and a $4-\mathrm{hr}$ incubation time, diamine oxidase activity was found to be a linear function of cell homogenate volume at least through $500 \mu \mathrm{g}$ of protein. Using a volume of cell homogenate containing $50 \mu \mathrm{g}$ of protein, diamine oxidase activity increased linearly with time through $24 \mathrm{hr}$ (data not shown). This information assured us that a 5-hr assay of cell homogenates containing 100-200 $\mu \mathrm{g}$ of protein would give diamine oxidase activities which varied linearly with the amount of enzyme present.

Figure 1 shows that $\mathrm{pH} 7.8$ is the optimal $\mathrm{pH}$ for diamine oxidase activity from crude homogenate of human fibroblasts. Because the fetal calf serum used to feed the cells contains a diamine oxidase activity against putrescine with a $\mathrm{pH}$ optimum of $8.0(12)$, it was necessary to show that the cellular enzyme, and not the fetal calf serum enzyme bound to the cells, was actually being assayed. Therefore, fibroblasts grown in adult bovine serum,

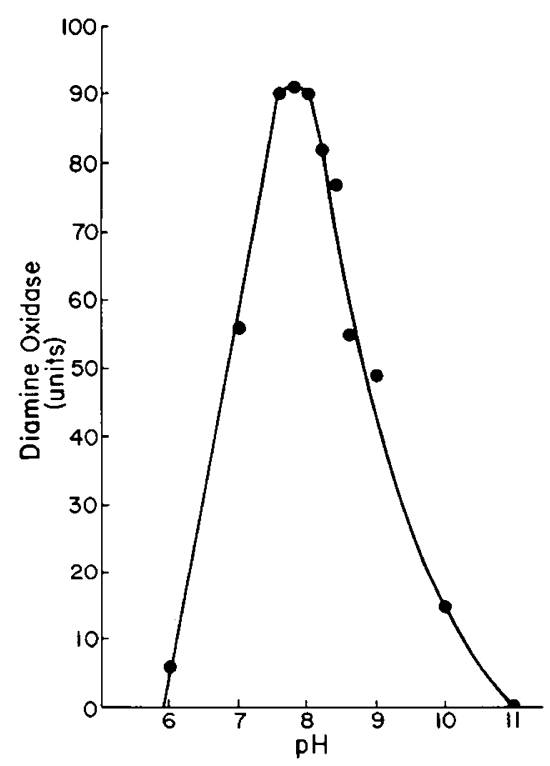

Fig. 1. Diamine oxidase activity of a human fibroblast strain at different $\mathrm{pH}$ values. Cells were grown to subconfluency in a roller bottle, washed, harvested, and homogenized. Homogenate volumes containing 75 $\mu \mathrm{g}$ of protein were incubated at $37^{\circ} \mathrm{C}$ in $1 / 15 \mathrm{M}$ potassium phosphate buffer of various $\mathrm{pH}$ values for $2 \mathrm{hr}$. The remainder of the assay procedure followed that described in the text. Blanks contained no cell homogenate. Results are means of triplicate determinations, with SD averaging less than $7 \%$ of the means. whose diamine oxidase activity against putrescine has an optimal $\mathrm{pH}$ of $9.8(12)$, were harvested and assayed for diamine oxidase activity. The $\mathrm{pH}$ optimum of the enzyme from the cell homogenate grown in adult bovine serum was approximately 8.0 (data not shown), indicating that the cellular and not the serum diamine oxidese was being assayed.

Figure 2 shows the ratio of protein to DNA plotted against day of harvesting. Day 1 is the 3rd day after plating, and the cells reached confluency approximately day 5 . Considering data on logarithmically growing cells, CF fibroblasts had less protein per $\mu \mathrm{g}$ of DNA than normal fibroblasts, though the difference was not significant at $P=0.05$. This difference between $C F$ and normal cells' protein content did not hold for confluent cells (day 8 ), whose protein/DNA ratio is much greater than that of logarithmically growing cells.

Table 1 gives the generation times in hr for protein content and cell count of six normal and six CF fibroblast strains from day 15 (logarithmic growth) in culture. No significant difference was observed between CF and normal cells. For both, the cells doubled in numbers in approximately $22 \mathrm{hr}$ and in protein content in approximately $28 \mathrm{hr}$. Protein was determined directly in each tissue culture dish for these calculations. DNA content in the P-60 dishes was often not substantial enough to give an accurate estimate of doubling times for DNA.

Figure 3 shows units of diamine oxidase per $\mu \mathrm{g}$ of protein as a function of day of harvesting for six normal and six CF fibroblast strains. All assays were performed on homogenized cells. The enzyme's specific activity remained stable at $1.5-2.0$ units/ $\mu$ g cell protein until the cells approached confluency. Then (day 8 ), only approximately 0.6 units of diamine oxidase per $\mu \mathrm{g}$ cell protein was found. No difference was noted between $\mathrm{CF}$ and normal cell strains.

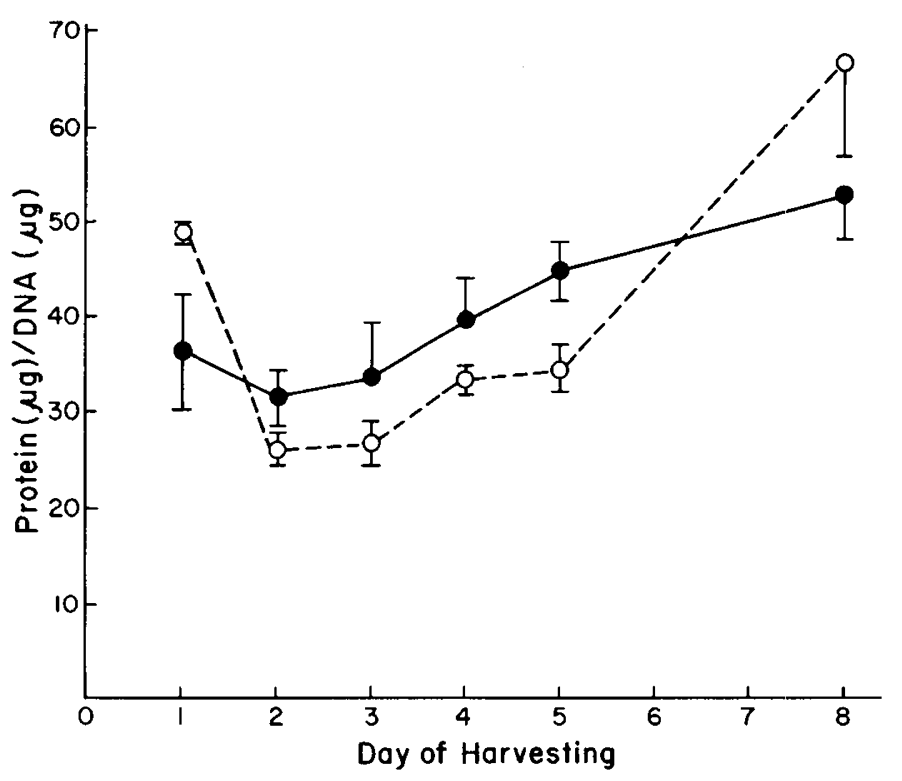

Fig. 2. Ratio of protein to DNA for different days in culture. - Normal strains. .... - CF strains. Each point represents the mean value of determinations for five fibroblast strains on the average. Brackets indicate SEM. Protein and DNA assays were performed on homogenates of each cell strain cultured in dishes, harvested, and pooled.

Table 1. Doubling times of normal and CF fibroblasts during logarithmic growth

Doubling time in $\mathrm{hr}$ (mean $\pm \mathrm{SE}$ )

\begin{tabular}{lccc}
\cline { 2 - 4 } & Normal & CF & $\begin{array}{c}\text { Number of paired } \\
\text { strains }\end{array}$ \\
\hline Cell number & $21.9 \pm 2.9$ & $22.5 \pm 2.4$ & 6 \\
Protein & $28.8 \pm 2.4$ & $26.9 \pm 0.8$ & 6 \\
\hline
\end{tabular}




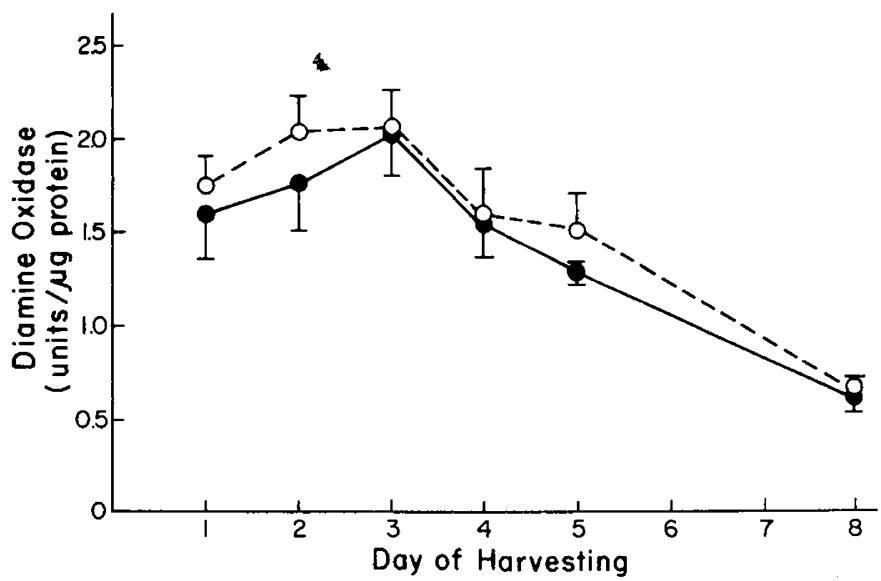

Fig. 3. Diamine oxidase activity (units/ $\mu$ g protein) of cell homogenates plotted against day of harvesting. - Normal strains. - . - - - CF strains. See text for details of assay procedures. Results are mean $\pm \mathrm{SE}$ of six normal and six CF fibroblast strains, each assayed for diamine oxidase in triplicate.

\section{DISCUSSION}

Current evidence suggests that polyamines play a vital role in growth $(2,8)$, and that polyamine biosynthesis, governed by the enzyme ornithine decarboxylase, is tightly controlled $(13,15)$. The regulation of polyamine degradation has not been pursued as extensively, but it is known that the enzyme diamine oxidase catabolizes polyamines to yield $\mathrm{H}_{2} \mathrm{O}_{2}, \mathrm{NH}_{3}$, and the substrate's respective aminoaldehyde (24). While different substrates have been utilized for the assay of diamine oxidase in the past, for the purification of the human seminal plasma diamine oxidase (14) and the human pregnancy plasma diamine oxidase (3), putrescine was employed, defining a human pregnancy plasma diamine oxidase with two subunits of 90,000 molecular weight. Purification of human amniotic fluid diamine oxidase using putrescine as substrate revealed two forms, the dimer and tetramer of a 110,000 molecular weight subunit (22). Whether these enzymes have activity against spermidine and spermine has not been proven, but ${ }^{14} \mathrm{C}$ putrescine remains the substrate offering the greatest sensitivity in the assay of diamine oxidase.

The present investigation shows that, while cellular protein content is relatively low during logarithmic growth of cells (Fig. 2 ), diamine oxidase activity reaches its peak (Fig. 3 ). In fact, the specific activity of the enzyme in rapidly dividing cells is three times that of confluent, minimally dividing cells (day 8), whose protein is accumulating. This modest increase in the fibroblast's capacity to degrade putrescine may permit the accumulation of polyamines during periods of growth, if synthesis is greatly increased.

The toxicity of spermidine and spermine to cultured human fibroblasts grown in medium containing fetal calf serum has been established (10). This inhibition of proliferation was considered to be due to the formation of toxic aldehyde products of polyamine degradation by diamine oxidase, known to be present in fetal calf serum (21). Aminoguanidine, a specific competitive inhibitor of diamine oxidase $(20,24)$, was shown to reverse the inhibition of fibroblast proliferation caused by spermidine and spermine (11). In the present study, the authors report the presence in human fibroblasts of a diamine oxidase whose activity is readily measurable and whose $\mathrm{pH}$ optimum is 7.8 (Fig. 1). The possibility that an intracellular diamine oxidase, inhibited by aminoguanidine, produces metabolites of spermidine and spermine toxic to human fibroblasts must now be entertained. However, this hypothesis assumes that spermidine, spermine, and aminoguanidine each enters the cell, an assumption for which there is currently no evidence.

Farrell et al. (9) found CF cells to have consistently lower protein/DNA ratios compared to normal cell strains growing logarithmically. The authors report similar results (Fig. 2). However, no differences in the doubling times for cell number or protein content were evident when comparing CF and normal fibroblasts in $\log$ growth. While this agrees with the previous report, doubling times in the present study were shorter, probably due to daily rather than twice-weekly media changes (9).

Although alterations in blood polyamine levels have been identified in CF $(7,19)$, no abnormalities in the effects of spermidine and spermine on adenylate cyclase (23), nor in the polyamine synthetic enzymes ornithine decarboxylase and S-adenosyl methionine decarboxylase have been found in CF fibroblasts (5). The present investigation shows no difference between CF and normal fibroblasts in the polyamine catabolic enzyme diamine oxidase (Fig. 3). Because fibroblasts express both the synthetic and the catabolic enzymes in polyamine metabolism, these combined results indicate that human fibroblast studies are not likely to reveal a defect in polyamine metabolism in CF.

This laboratory is currently investigating the relationship of cell polyamine levels to diamine oxidase activity and examining diamine oxidase for activity against spermidine.

\section{REFERENCES AND NOTES}

1. Arvanitakis, S. N., Mangos, J. A., McSherry, N. R., Rennert, O. M., and LaPointe, D.: Role of polyamines in cystic fibrosis (CF). Pediatr. Res., 7: 336 (1973).

2. Bachrach, U.: Function of Naturally Occurring Polyamines (Academic Press. New York, 1973)

3. Baylin, S. B., and Margolis, S.: Purification of histaminase (diamine oxidase) from human pregnancy plasma by affinity chromatography. Biochim. Biophys. Acta, 397: 294 (1975)

4. Baylin, S. B.: Histaminase (diamine oxidase) activity in human tumors: An expression of a mature genome. Proc. Natl. Acad. Sci. USA, 74: 883 (1977).

5. Buehler, B., Wright, R., Schott, S., Darby, B., and Rennert, O. M.: Ornithine decarboxylase and S-adenosyl methionine decarboxylase in skin fibroblasts of normal and cystic fibrosis patients. Pediatr. Res., 11: 186 (1977).

6. Burton, K.: A study of the conditions and mechanism of the diphenylamine reaction for the colorimetric estimation of deoxyribonucleic acid. Biochem. J.. 62: 315 (1956).

7. Cohen, L. F., Lundgren, D. W., and Farrell, P. M.: Distribution of spermidine and spermine in blood from cystic fibrosis patients and control subjects. Blood, 48: 469 (1976).

8. Cohen, S. S.: Introduction to Polyamines (Prentice Hall, Englewood Cliffs, NJ, 1971).

9. Farrell, P. M., Pallavicini, J. C., and Ulane, M. M.: Growth characteristics and protein content of tissue-cultured fibroblasts from cystic fibrosis patients. Proc. Soc. Exp. Biol. Med., 149: 340 (1975).

10. Gahl, W. A., Changus, J. E., and Pitot, H. C.: The effect of spermidine and spermine on proliferation in vitro of fibroblasts from normal and cystic fibrosis patients. Pediatr. Res., 10: 531 (1976).

11. Gahl, W. A., and Pitot. H. C.: Reversal by aminoguanidine of the inhibition of proliferation of human fibroblasts by spermidine and spermine. Chem.-Biol. Interac., 22: 91 (1978).

12. Gahl, W. A., and Pitot. H. C.: Putrescine oxidase activity in adult bovine serum and fetal bovine serum. In Vitro, 15: 252 (1979).

13. Heller, J. S., Fong. W. F., and Canellakis, E. S.: Induction of a protein inhibitor to ornithine decarboxylase by the end products of its reaction. Proc. Natl. Acad. Sci. USA. 73: 1858 (1976).

14. Holtta, E., Pulkkinen. P., Elfving, K., and Janne, J.: Oxidation of polyamines of diamine oxidase from human seminal plasma. Biochem. J., 145: 373 (1975).

15. Kay, J. E., and Lindsay, V. J.: Control of ornithine decarboxylase activity in stimulated human lymphocytes by putrescine and spermidine. Biochem. J., I32: 791 (1973).

16. Lowry, O. H., Rosebrough, N. J., Farr, A. L., and Randall, R. J.: Protein measurement with the Folin phenol reagent. J. Biol. Chem., 193: 265 (1951)

17. Okuyama, T., and Kobayashi, Y.: Determination of diamine oxidase activity by liquid scintillation counting. Arch. Biochem. Biophys., 95: 242 (1961).

18. Quissell, D. O., Changus, J. E., Yonan, T., and Pitot, H. C.: A partial characterization of human fibroblast plasma membranes isolated by the fluorescein mercuric acetate method of Barland and Schroeder. Anal. Biochem. 79: 240 (1977).

19. Rennert, O. M., Frias, J., and LaPointe, D.: In: J. A. Mangos: Fundamental Problems of Cystic Fibrosis and Related Diseases, pp. 41-52 (Intercontinental Medical Books, New York, 1973).

20. Shore, P. A., and Cohn, V. H. Jr.: Comparative effects of monoamine oxidase inhibitors on monoamine oxidase and diamine oxidase. Biochem. Pharmacol., 5: $91(1960)$

21. Tabor, C. W., Tabor, H., and Bachrach, U.: Identification of the aminoaldehydes produced by the oxidation of spermine and spermidine with purified plasma amine oxidase. J. Biol. Chem., 239: 2194 (1964).

22. Tufvesson. G.: Purification and properties of human amniotic fluid diamine oxidase. Scand. J. Clin. Lab. Invest., 38: 463 (1978).

23. Wright, R. K., Buehler, B. A., Schott, S. N., and Rennert, O. M.: Spermine and 
spermidine, modulators of the cell surface enzyme adenylate cyclase: Pediatr. Res., 12: 830 (1978).

24. Zeller, E. A.: In: P. D. Boyer, H. Lardy, and K. Myrback: The Enzymes, Vol. 8, pp. 313-335 (Academic Press, London, 1963).

25. The excellent technical assistance of Ann Vale and Naomi Williams is gratefully acknowledged.

26. Biopsies were obtained from patients with their informed consent and with the approval of the University of Wisconsin Committee for the Protection of
Human Subjects.

27. Requests for reprints should be addressed to: William A. Gahl. M. D., McArdle Laboratories, the Center for Health Sciences, University of Wisconsin Madison, Wisconsin 53706.

28. This research was supported in part, by a grant from the Cystic Fibrosis Foundation.

29. Received for publication December 1. 1978.

30. Accepted for publication February 13, 1979.

Copyright (C) 1980 International Pediatric Research Foundation, Inc. $0031-3998 / 80 / 1402-0118 \$ 02.00 / 0$ 